\title{
Who Refers Most? Institutional Incentives and Judicial Participation in the Preliminary Ruling System
}

\author{
Arthur Dyevre $^{1}$, Monika Glavina², Angelina Atanasova ${ }^{3}$
}

\begin{abstract}
By enabling the Court of Justice to engage domestic judges, the preliminary ruling mechanism is widely recognized to have played a major role in European integration. Yet both the incentives and motivation to cooperate with the Court of Justice are believed to vary significantly across domestic courts. We explore how domestic courts differ in their referral behaviour depending on the position they occupy in the juridical hierarchy using a novel dataset, which extends, complements and corrects data initially collected by Stone Sweet and Brunell (1998). We find that first instance courts pioneered the use of the preliminary ruling procedure, but that appellate and peak courts subsequently overtook them. We explain these shifts by the combined effect of institutional consolidation, organisational design and legal rules. We argue that resort to Article 267 TFEU was initially "accidental" but became institutionalised as more courts submitted references. This, in turn, allowed the division of labour underpinning the organisation of national judiciaries to reshape referral dynamics.
\end{abstract}

Key words

ECJ, EU judicial politics, institutionalisation, team model, judicial behaviour

Key words

preliminary ruling mechanism, ECJ, domestic courts, institutionalisation, team model, judicial behaviour

\footnotetext{
${ }^{11}$ Corresponding author: KU Leuven, Political Science Department, Leuven, Belgium; E-mail: arthur.dyevre@law.kuleuven.be; Phone: +3216325387

${ }^{2}$ KU Leuven, Political Science Department, ; E-mail: monika.glavina@kuleuven.be

${ }^{3}$ KU Leuven, Political Science Department; E-mail: monika.glavina@kuleuven.be
} 


\section{Introduction}

That the preliminary ruling system set up by Article 267 of the Treaty on the Functioning of the European Union (TFEU) has been central to the construction of the European Union legal order is a commonplace. Article 267 has been credited for much of what the European Court of Justice (ECJ) has achieved, from the landmark cases that paved the way for the constitutionalisation of EU law to the doctrines that bolstered the economic and social integration of the continent (Alter 2006; Burley and Mattli 1993; Conant 2006; Craig and de Búrca 2015; Stone Sweet and Brunell 1998). Allowing the development of an interlocutory partnership with national judges, the procedure has supplied the steady stream of cases without which the ECJ would never have morphed into the judicial colossus it has become (Alter 2001; Stone Sweet 2004).

Efforts to understand referral dynamics have spawned a cottage industry of Article 267 studies. Straddling the disciplines of law and political science, this literature has considered how referral activity varies across time, Member States and echelons of the judiciary. Scholars have sought to explain variations in judicial participation in Article 267 proceedings by variously pointing to differences in judicial attitudes and educational background (Alter 2001; Golub 1996; Mayoral, Jaremba, and Nowak 2014); patterns of transnational economic exchange (Stone Sweet and Brunell 1998); public support for integration (Carrubba and Murrah 2005); democratic aversion to judicial power (Wind 2010; Wind, Martinsen, and Rotger 2009); legal culture, including litigiousness (Broberg and Fenger 2013, 2014a); economic clusters (Kelemen and Pavone 2016) and specialised law firms (Kelemen and Pavone 2018). One strand of research, though, has focused on institutional differences among domestic courts, emphasising the impact of lower court empowerment (Weiler 1991, 1994), inter-court competition (Alter 1998, 2001), jurisdictional specialisation (Conant 2001; De la Mare 1999) and judicial centralisation (Kelemen and Pavone 2018). Some of these accounts of referral dynamics are essentially narratives of the integration process without an explicit basis in hard empirical data (e.g. Weiler 1991). Other studies, although primarily qualitative in their approach, have nonetheless sought to provide some empirical support for their theoretical claims. The evidence provided has varied significantly in geographical and temporal scope. Most studies have considered crosscourt variations in two or three member states (e.g. Alter 2001; Conant 2001; Kelemen and Pavone 2018). However, one, conducted by Alec Stone Sweet and Thomas Brunell, is considered a more comprehensive cross-section of domestic courts. Taking issue with Karen Alter's court competition hypothesis, it 
documented the referral activity of first instance, intermediate and top courts in the period 1961-1995. Stone Sweet and Brunell found patterns inconsistent with Alter's theory:

"[O]ver the entire life of the Community, appellate courts have been more active than lower courts in referring questions to the European Court. If we consider the fact that there are many more lower than appellate courts, and that lower courts process the vast bulk of national litigation, this discrepancy is all the more striking. Because a core function of appellate judging is to resolve disputes involving legal interpretation and conflict of law, we would expect the appellate courts to be far more involved in the construction of the legal system than Alter imagines them to be." (Stone Sweet and Brunell 1998: 90)

Since Stone Sweet and Brunell's seminal study, though, no serious attempt has been made to return to the issue to document disparities in referral dynamics across levels of the judiciary in comprehensive fashion. How have these dynamics changed after 1995? What is the situation prevailing in the 16 countries that have joined the EU since then? The EU has experienced major institutional, political and doctrinal developments - some brought about by treaty revisions, others by ECJ rulings — since the mid-1990s. We may reasonably expect them to influence judicial attitudes towards EU law and Article 267 use. These questions are as important now as they were twenty years ago. They have implications for our understanding of the extent to which EU law permeates domestic legal systems as well as for how the judicial venue may affect a litigant's ability to bring an issue before the Court of Justice.

The present paper develops a new theoretical account of referral dynamics and adduces new data to substantiate it. Our approach incorporates insights from management-based theories of judging (Epstein, Landes, and Posner 2013), team models of inter-court interactions (Kornhauser 1994) and theories of institutional change (Brousseau and Raynaud 2011; Kingston and Caballero 2009). Specifically, we argue that larger resources together with a focus on law-finding and law creation constitute, in principle, strong incentives for peak courts to make use of the preliminary ruling mechanism. However, at the start of the integration process EU law was an obscure body of law and domestic courts, at all echelons of the domestic judicial pyramid, had few reasons to consider it relevant to the business of adjudication. We claim that lower courts' use of Article 267 TFEU in this period was "accidental" but that accidents were sufficiently numerous to kick-start an institutionalisation process. As a result, peak courts started giving more attention to EU law and this, in turn, allowed the division of labour underpinning the organisation of national judiciaries to reshape referral dynamics. Eventually, as litigants and peers began to expect peak judges to uphold the letter of Article 267, peak courts faced pressure to submit more. To substantiate our analysis and assess the empirical plausibility of competing accounts of referral participation, we deploy a new dataset that extends, revises and supplements the data originally collected by Stone Sweet and Brunell. Covering 
57 years of referral activity, our data documents referral patterns for the different levels of courts as well as for their subject matter jurisdiction. Our analysis shows that first instance courts pioneered use of the preliminary ruling procedure. However, consistent with the accidental use hypothesis, these courts have been somewhat volatile in their use of Article 267. Meanwhile, peak courts, and, to a lesser extent, intermediate appellate courts too, have steadily caught up on them. To the point that, following the 2004 enlargement, peak courts have overtaken lower and intermediate level courts in absolute referral rates. Thus a small number of peak accounts for almost forty per cent of all referrals. Although the institutional setup of courts vary substantively across member states, this trend is apparent in most of them. We provide evidence that referral propensity relates to variations in workload that stem from the national judiciaries' underlying division of labour.

The paper is structured as follows. Section Two discusses the explanations and theories of adjudication that have been advanced for inter-variations in referral propensity. Section Three sets out our own, preferred theoretical account, which blends various strands of theoretical thought on law and judges. Domestic judges, we argue, are subject to a variety of incentives and constraints that affect their referral behaviour. One source of behavioural divergence arises from the demands of caseload management and the resources available to handle it. Another stems from the evolving institutional environment in which national courts operate. The combination of greater resources and a smaller workload means that the opportunity cost of requesting a preliminary ruling are lower for higher courts. But the effect of these factors has been mediated by the degree of institutional consolidation of European law. Low levels of institutionalisation had the effect of initially blunting their influence. But, as integration progressed and peak courts came under greater pressure to comply with their obligation under Article 267 TFEU, institutionalisation has, on the contrary, worked to amplify their impact. Next, Section Four presents our data and methodology while Section Five reports our results. We conclude with some thoughts on the impact of the political crisis that has marred the European project in recent years on national courts.

\section{Debates and Theoretical Perspectives}

\section{The Legal Model}

Legal scholars do not articulate their account of referral activity in terms of a "model" or "theory" of adjudication in the manner social scientists do and one would look in vain for an explicit articulation of the "legal model". ${ }_{4}^{4}$ Still, when seeking to elucidate the conduct of national courts, it is true that legal academics typically accord priority to legal factors (Claes 2006). Assuming that judges respond primarily to legal

\footnotetext{
${ }^{4}$ What judicial scholars call the "legal model" is, in fact, their own reconstruction of the conception of judicial decision making they attribute to judges and law professors, see Stephenson (2009).
} 
stimuli, one can first point to the plain meaning of Article 267 TFEU as possible driver of behavioural differentiation. As it is well known, Article 267 distinguishes between national courts "against whose decisions there is no judicial remedy under national law" and all the other national courts that do not fit this definition. As to the former, it specifies that, when the interpretation of EU law is material to the case, a preliminary ruling "shall" be requested — which implies an obligation. With regard to latter, by contrast, it states that in such cases a preliminary ruling "may" be requested - which implies discretion. The language of Article 267 must, of course, be considered in light of the ECJ's determinations regarding the obligations of peak courts, most notably the acte clair doctrine first articulated in its CILFIT ruling. The doctrine stipulates that the obligation does not apply where the ECJ's ruling would have no bearing on the final decision in the main proceedings before the national court. Likewise, the obligation does not hold when the ECJ has already ruled on an identical question; has already provided an interpretation of the same provision of EU law (referred to as acte éclairé); or the interpretation of the EU law provision is so obvious as to leave no reasonable doubt (acte clair). Even taking these doctrinal refinements into account, the legal model suggests that last instance courts should submit more references than courts lower down the judicial hierarchy. Note, though, that since the wording of Article 267 has remained unchanged, the legal model predicts that peak courts will always refer more than other courts, regardless of the stage of European integration or of non-legal factors.

\section{Judicial Empowerment}

The other conceptions of judicial motivation put forward in the Article 267 literature go beyond pure legal considerations. In fact, they are explicitly premised on the notion that judges seek to expand their power. This presumption was central to Weiler's empowerment hypothesis:

"[N]ormative acceptance of the ECJ constitutional construct and practical utilization through the Article [267] process by national courts may be rooted in plain and simple judicial empowerment. [...] Has not power been the most intoxicating potion in human affairs?" (Weiler 1994: 523).

Weiler argued that domestic courts which did not hold the power of constitutional review under domestic law would be more inclined to use EU law. This was because through the Court of Justice and Article 267 these courts could acquire the right to set aside parliamentary legislation. A right hitherto inexistent in their legal system or one that had remained the exclusive preserve of specialised, constitutional judges. Of the judicial empowerment that accompanied the integration process Weiler wrote:

"The empowerment was not only, or even primarily, of the European Court of Justice, but of the Member State courts, of lower national courts in particular. Whereas the higher courts acted diffidently at first, the lower courts made wide and enthusiastic use of the Article [267] procedure. This is immediately 
understandable both on a simple individual psychological level and on a deep institutional plane. Lower courts and their judges were given the facility to engage with the highest jurisdiction in the Community and thus to have de facto judicial review of legislation. For many this would be heady stuff." (Weiler 1991: 2426).

Insofar as constitutional review existed at all in the countries that joined the European Union, centralised review was the norm. So the empowerment hypothesis suggested that most domestic judges would be keen to request references, at least to the extent that litigants raised EU law questions in the disputes brought before them. Yet it implied that constitutional courts would be the least enthusiastic users of the preliminary ruling system, as they had no additional powers to win from EU law. ${ }^{5}$

\section{Court Competition}

Akin, yet distinct from the empowerment hypothesis is the court competition hypothesis. The hypothesis was originated by Karen Alter, who saw it as an extension and refinement of Weiler's empowerment narrative (Alter 1996). As its name implies, the court competition hypothesis emphasised rivalry among domestic courts as a motive for Article 267 use. Inter-court rivalry gave lower courts, in particular, greater incentives to submit references. Alter's focus on lower courts was not, in itself, new. In his articulation of the empowerment hypothesis, Weiler, too, discussed the position of lower courts. And he, too, saw the procedure as enjoying great popularity among lower courts (Weiler 1994, 523) - a view echoed in the work of other scholars at the time (see Burley and Mattli 1993, 63). Unlike Alter, however, Weiler did not expressly mention the possibility for lower courts to use the procedure as a means to circumvent their judicial hierarchy. The empowerment narrative was primarily concerned with the preliminary ruling procedure as a means to expand the courts' power against the other branches of government. Alter's argument, by contrast, placed greater emphasis on dynamics within judiciaries. She contended that lower domestic courts seeking to change the doctrinal status quo could use Article 267 to "appeal" before the CJEU against their higher courts' jurisprudence:

"Lower court judges, with the luxury of focusing only on the case at hand, are usually less concerned with the coherence of the national legal system. In addition, the preliminary ruling mechanism allows lower courts to appeal to an authority outside the national legal system, securing an authoritative counter-precedent to the interpretations of national supreme courts. As long as a lower court agrees with ECJ interpretations, ECJ decisions actually lend legal credibility to a lower court decision and thus bolster the influence of the lower court within the national legal system. As such, references to the ECJ have become a convenient means to circumvent higher courts. The ECJ is like a second parent in a battle where parental permission wards off a potential sanction for misbehaviour-if the lower court does not like what they think one parent (the higher

\footnotetext{
${ }^{5}$ Weiler, though, did not explicitly draw out the implications of his argument in terms of constitutional courts vs other courts and generally lumped together administrative supreme courts like the French Conseil d'Etat and constitutional tribunals like the German and Italian constitutional courts, see Weiler (1994: 521).
} 
court) will say, they can ask the other parent (the ECJ) to see if they will get a more pleasing answer." (Alter 2001: 48).

Other scholars had already noticed the possibility Article 267 offered to lower domestic courts to rebel against their hierarchy (see in the British context Rawlings 1993, 320), but did not go as far as Alter in generalising this phenomenon. In any case, Alter clearly hypothesised that lower courts should, in general, be more willing to use the preliminary ruling mechanism.

\section{Subject Matter Jurisdiction and Litigation Patterns}

Finally, EU scholars have considered how subject matter jurisdiction and litigation dynamics affect referral propensity. De la Mare posited that more specialised national courts would send preliminary references to Luxembourg with greater frequency. The claim follows from the presupposition that highly specialised courts use EU law more extensively in their daily work and, therefore, have more reasons, as well as more opportunities, to raise references. Non-specialised courts, on the other hand, operate across multiple, often heterogeneous legal domains and their experience with EU law is more diffuse. So they are likely to attempt to solve EU law questions on their own, without getting the CJEU involved, when these arise (de la Mare 1999: 215). Along similar lines, Broberg and Fenger observed that courts specialising in VAT or customs disputes deal almost exclusively with regulations that result from the transposition of EU law into domestic law. Consequently, the cases that reach these courts virtually always involve EU law. On account of their constant exposure to EU law, courts falling in this category are better at spotting EU law issues that may require elaboration from the Court of Justice (Broberg and Fenger 2014: 56).

Also invoking jurisdictional specialisation is Lisa Conant. Discussing the limits of the reach of EU law, she stressed the narrow base and high access costs of EU law litigation and argued that, as a consequence, courts dealing with commercial disputes are more likely to raise preliminary references (Conant 2001: 109). Her argument entails that civil and commercial courts should be frequent submitters but administrative courts less so. A similar line of reasoning led Stone Sweet and Brunell to suggest that constitutional and administrative courts would be less likely to pass on references to the Court of Justice (Sweet and Brunell 1998, 91).

\section{Judicial Centralisation}

Finally, in a recent contribution, Daniel Kelemen and Thomas Pavone argue that the structure of the domestic judicial order can determine the degree to which national peak courts control the use of EU law and, through it, domestic participation in the preliminary ruling procedure: 
"When state judiciaries are decentralized, the spread of EU law will be more incrementally driven from the bottom up by autonomous lower courts, exhibiting greater subnational variation even as the number of cases referred to the ECJ steadily increases over time. When state judiciaries are centralized, the penetration of EU law will be more temporally volatile and driven from the top down by supreme courts, which can leverage their authority to uniformly dissuade or promote preliminary references from lower courts throughout the state's territory." (Kelemen and Pavone 2018: 361-2.)

Their analysis concludes that in all three countries investigated-France, Italy and Germany—national supreme courts have affirmed greater control over the preliminary ruling mechanism. But they find the trend to be more pronounced in France, which they attribute to the highly centralised character of the French judiciary (Kelemen and Pavone 2018).

\section{Institutional Consolidation and the Organisational Structure of National Judiciaries}

Our alternative account of referral dynamics draws on research in law and economics as well as political science. Basically, our argument rests on two prongs. The first prong emphasises the incentives arising from the organisation structure of national judiciaries while the second stresses the informal dynamics that have led to the institutional consolidation of judicial cooperation in the context of Article 267.

According to the team model of adjudication, a hierarchically arranged court system can be conceptualised as a team striving to maximize the number of "correct" outcomes. The manner in which resources and caseload are typically allocated across tiers of courts ensures an efficient division of labour. Lower courts concentrate on fact-finding whereas higher courts specialise in law-finding and law creation. Lower courts judges have less time to expend on individual cases while higher courts have more, leaving extra resources to expend on law-finding and law creation (Kornhauser 1994, 1999; Romeu 2006). We follow the team model of adjudication in assuming that the division of labour within national judiciaries broadly conform to the fact-finding vs law-finding distinction. Whether in common law countries like the UK and Ireland or civil law jurisdictions such as France and Germany, appellate review at peak court level is normally restricted to points of law. Lower courts effectively focus on individual dispute resolution while the courts at the apex of the pyramid handle the doctrinal and interpretive issues that transcend individual cases (Romeu 2006, 397). Because a referral and the ensuing preliminary ruling can only address points of law, the Article 267 procedure relates more directly to the specialisation of peak courts than to that of first instance courts. On that score, we think that, contrary to Karen Alter, the lower courts' "luxury to focus only 
on the case at hand" usually works as a counterincentive to submit references. If we accept that developing legal doctrines is a resource-intensive activity and not merely an exercise in power-assertion, then we must recognise that higher courts generally have more to gain from outsourcing law-finding to the ECJ than lower courts.

Highlighting the multiple interests, needs and personal obligations that judges pursue simultaneously, the labour market theory of judging helps to refine our understanding of how the trade-offs to which these preferences give rise affect judicial behaviour (Epstein, Landes, and Posner 2013, 7). ${ }^{6}$ Judges must decide how to allocate their time between judicial and non-judicial activities, which has a direct bearing on the amount of effort they are able to invest in law-finding and opinion-writing (see Ash and MacLeod 2015; Epstein, Landes, and Posner 2013). Consistent with the labour market theory, we assume that judges want to be perceived as doing their job well—whether fact-finding, opinion-writing, law-finding or lawcreation - but also have other preferences, including family and leisure time. These preferences compete for a judge's time. Getting home early on Friday night means less time to work on one's caseload, and viceversa. Time represents a resource constraint for all judges because there are only 365 days in a year and 24 hours in a day. Everything a judge does-from getting rest to writing opinions-must fit this constraint (Ash and MacLeod 2015). Because resources and caseload differ across tiers of courts within domestic judicial hierarchies, the trade-offs induced by this constraint vary across the echelons of the judiciary. Support in the form of law clerks and assistants can, of course, mitigate constraining effect of time on the decision to write a dissent or a request for a preliminary ruling. Yet not all domestic judges have access to such resources. In fact, those enjoying the highest level of staff support are typically those sitting at the top of the judicial pecking order. These judges are also more likely to have access to a state-of-the-art library, online databases and a research unit.

As shown in Figure 1, first instance judges tend to handle a significantly larger number of cases per year than intermediate and peak court judges. Apparent, exceptions, such as Romanian and Swedish supreme court judges, can be explained away by docket control mechanisms. (Many of the cases lodged with supreme courts are disposed of by means of formal dismissals, with little or no reasoning.)

\footnotetext{
${ }^{6}$ Unlike trade-offs between judicial tasks (fact-finding, law-finding and law-making), trade-offs between judicial and non-judicial activities are not addressed by the team theory of adjudication. In that respect, the team and labour market perspectives complement each other.
} 


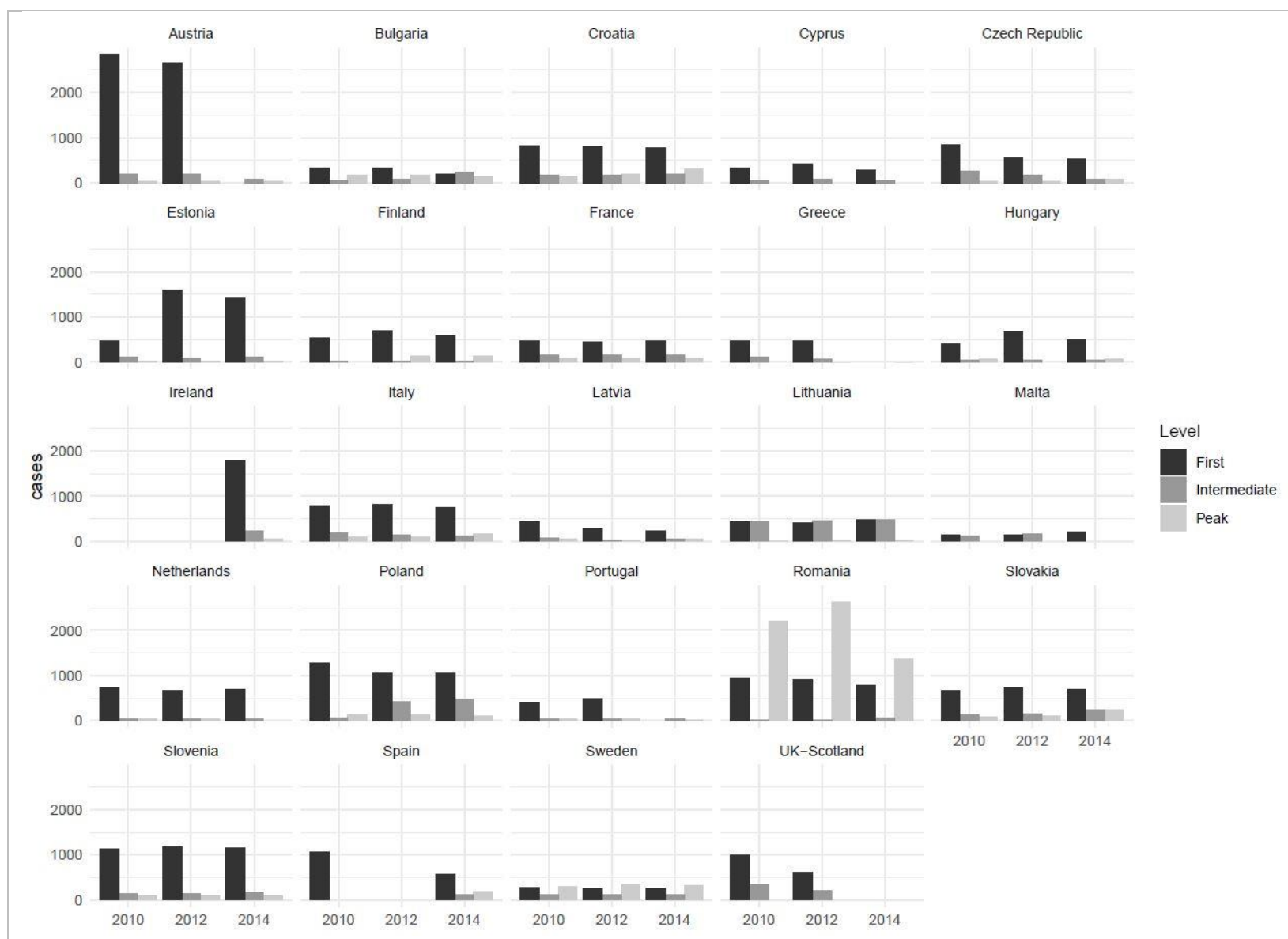

Figure 1. Average number of cases per judge by tier of courts in $26 \mathrm{EU}$ member states, civil cases. (Data source: CEPEJ.)

As a consequence of facing distinct resource/caseload ratios, lower and higher court judges do not associate the same opportunity costs with participation in the preliminary ruling procedure. In general, the lower the resource/caseload ratio - that is, less judicial time for more cases - the larger these opportunity costs are likely to be. The time and effort required to draft a preliminary reference is not inconsiderable, especially as admissibility requirements have become stricter over time. More importantly, the time and effort invested in preparing, drafting and submitting a reference are as much time and effort that cannot be used for something else, such as disposing of cases already on the court's docket or spending time at home with family and friends. If we accept that "judges want to dispose of their workload efficiently and to go home at the end of the day knowing that they solved more rather than less work problems" (Sweet and Brunell 1998, 73), writing a reference and then wait 18 months (the ECJ's average processing time) for the preliminary ruling may not be the most effective way to achieve it when several hundred cases on their docket are awaiting resolution. To summarise, considerations pertaining to the division of judicial labour and the opportunity costs of referring arising from the judges' resource/caseload ratio both suggest that, 
other things being equal, peak courts should submit more. For lower courts, the benefit of cooperating with the ECJ only extends to the dispute at hand, while for peak and appellate courts it extends to all disputes with similar fact patterns. Given the large opportunity costs a first instance judge is likely to face, the benefit to the parties or to the judge's conception of justice in the dispute at hand will have to be exceptionally high to spur her to request a preliminary ruling. To be sure, because lower court judges are so numerous - they outnumber supreme court judges by two orders of magnitude - and adjudicate millions of disputes every year, there might be enough exceptional disputes of this kind to account for a good share of a rising stream of references. Yet this does not diminish the fact that a reference will represent an exceedingly rare event at lower court level. One which most lower court judges will never experience in their entire judicial career.

Given what we just said, it may seem counterintuitive that our theoretical framework allows for the possibility that lower courts will refer more, at least in aggregate, in the early stages of the integration process. Here we appeal to the second building block of our theory, which specifies how the self-reinforcing logic of institutional consolidation influences the conduct of higher court judges. When an international regime is its infancy, its base of supporters at domestic level is extremely narrow (Alter 2012). This certainly applied to their European Union in its foundational period (Weiler 1991). From the perspective of domestic courts, the ECJ looked as a relatively obscure judicial body which they had little reason to take seriously. For that reason, we explain early references as isolated "accidents". Judges ignored EU law and Article 267 in virtually all cases. Only exceptionally would judges and parties give collaboration with the new international regime a try. Yet owing to the sheer number of lower court judges and lower court cases, the tiny fraction of disputes in which both the parties and the judge were willing to file a reference was still large enough to kick-start an informal institutionalisation process. As more litigants and judges began to recoordinate around the new regime, peak courts could no longer ignore the formal rules laid down in Article 267. "Local and voluntary" cooperation thus gradually turned into a "generic and mandatory" requirement (Brousseau and Raynaud 2011). ${ }^{7}$ As more domestic actors came to expect judges to uphold the rules of the international regime, even recalcitrant courts found themselves locked-up by the self-reinforcing logic of institutionalisation. ${ }^{8}$ They were soon faced with a choice between accepting integration and enduring increasing isolation. Supreme court judges who ignored the letter or spirit of Article 267 and never submitted references exposed themselves to growing criticism. Then, once EU law had reached this level of institutional consolidation, it was only a matter of time for the organisational structure of national judiciaries

\footnotetext{
7 We leave elaborations regarding the exact chronology — when voluntary cooperation became a generic and mandatory commitment — and geography — possible disparities across member states and judiciaries — of the posited institutionalization process to future research.

${ }^{8}$ Arguably, this aspect of argument bears strong affinity with historical institutional accounts of European integration drawing on the notion of path dependence, see Pierson (1996).
} 
to assert its full effect. Courts with higher resource/workload ratio - that is apex courts and, to a lesser extent, intermediate courts - would gradually come to dominate the preliminary ruling system.

\section{Data and Methodology}

Our dataset builds off from the efforts of Alec Stone Sweet and Thomas Brunell, whose dataset we extended, revised and supplemented in several ways (Sweet and Brunell 1998). First, we collected all the references submitted between 1 January 2007 and 31 December 2017, thereby adding more than four thousand observations to the original dataset. Like Stone Sweet and Brunell, we collected the following information for every reference: filing date, case number, case outcome (order, judgment, pending...), member state of origin, name of referring court and area of EU law affected. Second, while coding these references, we corrected several mistakes in the original dataset, including many errors in the names of the referring courts. Finally, we added two new variables to the dataset: (1) the position of the referring court in the judicial hierarchy, and (2) the subject matter jurisdiction of the referring court. Most of the information was coded from the CJEU's official website, Curia. To determine the position of the referring courts in the court system, we further relied on the European Judicial Atlas published by the European Commission as well as on the ECJ's guide to national judiciaries Juridictions des États membres de l'Union européenne. ${ }^{9}$

Establishing the hierarchical position of a judicial body is not always straightforward. Surprisingly, even though much has been written about the alleged differential in referral rates between higher and lower courts, judicial scholars have not provided explicit operationalisations to identify these categories across member states (Sweet and Brunell 1998: 71). Sweet and Brunell divide domestic courts in three groups: (1) lower courts, (2) intermediate courts, and (3) higher courts (Sweet and Brunell 1998: 89). Yet the codebook accompanying their dataset does not specify the criteria used to implement this classification. Our classification scheme identifies courts according to five categories: (1) first instance; (2) second instance; (3) peak; (4) single instance; and (5) non-judicial. A first instance court was defined as a court with original jurisdiction against whose decisions a judicial remedy exists; an intermediate or second instance court as a court with jurisdiction to hear appeal from first instance courts; a peak court as a court with jurisdiction to review the decisions of intermediate courts; and a single instance court as a court with original jurisdiction but against whose decisions no judicial remedy exists. Owing to the sometimes complex juxtaposition of original and appellate jurisdiction, we took the category "peak court" to include all supreme courts and constitutional courts, even when these occasionally exert original jurisdiction. As for non-judicial bodies, the category subsumes a varied set of entities, encompassing regulatory bodies, anti-discrimination

9 (CURIA - Courts of the Member States of the European Union - Court of Justice of the European Union n.d.) http://curia.europa.eu/jcms/jems/Jo2_7231/fr/ 
agencies, data protection watchdogs and advisory commissions. The typology and categories used to code the courts' subject matter jurisdiction are explained in the Appendix.

Although our analysis relies mostly on descriptive statistics, we also use regression analysis to evaluate the effect of workload and hierarchy on referral propensity. To that end we construct a measure of referral propensity by dividing the number of referrals for all courts in tier $i$ in country $j$ in year $t$ by the number of judges $J$ in tier $i$ in the same country in the same year. Because this index is not normally distributed - the index cannot take negative values but it has $\mathrm{M}=0.09$ and $\mathrm{SD}=0.42$-we take its natural $\log$ to make it normally distributed:

$$
\text { Average Referral Propensity }=\log \left(\frac{\text { Referrals }_{i j t}}{J_{i j t}}\right)
$$

We regress this index on the CEPEJ data in Figure 1 and hierarchical position applying OLS regression. We control for both country and year, which guarantees that our results are robust to unobserved countryspecific variations as well as to variations in referral dynamics induced by EU-level events (e.g. new directive or new ECJ case law).

\section{Results}

This Section reports the results of our analysis. Results for subject matter jurisdiction are reported in the Appendix. As explained there, with the possible exception of German tax courts, we could find no conclusive evidence in our data that specialised courts submit more references, as Broberg and Fenger (2014) and De la Mare (1999) had claimed. Nor, contrary to Stone Sweet and Brunell (1998), could we find evidence that administrative courts are more reluctant to participate in the preliminary ruling system. The remainder of this Section concentrates on cross-tier variations.

Plotted in Figure 2 is the evolution of referral rates by court level over the lifetime of the EU. It is easy to see what led scholars writing in the 1990s to emphasise the role of lower courts in legal integration. Looking back at three decades of referral activity, lower courts had clearly been the most frequent submitters, at least in absolute terms. It was easy to come under the impression that lower courts were the ones driving legal integration forward. This, however, overlooked steadily rising referral rates for peak and second instance courts. At the turn of the millennium, peak courts overtook first instance courts and, since the mid-2000s, they consistently raise as many if not more preliminary references than first instance courts. The gap between first instance and intermediate courts has also shrunk. This evolution looks even more remarkable when we consider that there are several thousand first instance courts, but far fewer appeal courts, and only 65 peak courts in the entire European Union. Another interesting contrast between lower 
and higher courts is volatility. The curve for first instance courts in Figure 2 reveals lots of marked peaks and valleys, whereas fluctuations around the long term trend are far less pronounced in the case of peak and second instance courts. This is consonant with our theoretical account and, in particular, with our claim of the "accidental" character of first instance courts' participation in the preliminary ruling system. The wild random fluctuations that seem to characterise their referral activity suggest that the use of the preliminary ruling system is determined by rare, contingent features of legal disputes interacting with the idiosyncratic personal attributes of the judges called on to adjudicate these disputes.

The organisational setup of national judiciaries is subject to significant cross-country variations. Yet Figure 3 reveals that these patterns hold across most member states. In Belgium, France and the Netherlands, all three founding member states, lower courts used to dominate Article 267 proceedings. But, as integration progressed, they have been gradually overtaken by peak courts. Higher peak court involvement in referral proceeding can also be observed in Austria, the Czech Republic, Germany (since the late 1980s, except for a blip in lower court activity in 2017), Finland, Greece, Ireland, Latvia, Lithuania, Poland, Portugal and Slovenia. Only in Hungary and Bulgaria do first instance courts continue to refer more than the courts above them. Italy would seem to be an outlier given the exceptionally high level of referral activity of its lower judicial bodies. Yet Italy, too, has experienced a catching-up process, with peak and first instance courts virtually tied since 2013-14. Also confirmed by our cross-country analysis is the greater volatility of lower courts' involvement in the preliminary ruling procedure. The more conspicuous blips in Figure 3 mostly result from fleeting surges in preliminary references originating from first instance courts.

The regression results presented in Table 2 suggest that referral propensity is associated with hierarchical position as well as with workload. Model (1) shows that judges' average workload has a negative and significant effect on referral propensity. Looking only at the regression coefficient, the effect may seem small, but this is the effect on average referral propensity of a one-unit change in workload on a single judge. Model (2) shows that, other things being equal, judges on intermediate and apex courts have a higher referral propensity. With adjusted $R^{2}=0.71$ (against $R^{2}=0.32$ for the regression without judicial hierarchy), the model implies that hierarchical position is a strong predictor of referral propensity. Workload and hierarchical position are strongly correlated (as is obvious from Figure 1). So including them in the same model specification results in reduced effect size and significance. This is what model (3) demonstrates. The coefficient for intermediate and apex tiers is smaller while the standard errors are slightly larger. The effect of workload remains positive and significant but only at the $p<0.1$ level. Still, given that country and year fixed effects reduce the power of our model, this suggests that judges face trade-offs between judicial tasks (fact-finding, law-finding and law-creation) as well as between judicial and nonjudicial activities when considering participation in the preliminary ruling system. 
The workload data is imperfect (only tier-level) and limited in its temporal coverage (only available for 2010, 2012 and 2014). But even so, these results indicate that referral propensity is affected by both the division of labour among tiers of courts and underlying differential in workload.

\begin{tabular}{|c|c|c|c|}
\hline & \multicolumn{3}{|c|}{$\begin{array}{l}\text { Dependent Variable: } \\
\text { Average Referral Propensity }\end{array}$} \\
\hline & (1) & (2) & (3) \\
\hline Average Workload per Judge & $\begin{array}{c}-0.0003 * * \\
(0.0001)\end{array}$ & & $\begin{array}{l}-0.0001 * \\
(0.0001)\end{array}$ \\
\hline Intermediate Tier & & $\begin{array}{c}1.241 * * * \\
(0.286)\end{array}$ & $\begin{array}{l}1.10 * * * \\
(0.295)\end{array}$ \\
\hline Peak Tier & & $\begin{array}{c}3.312 * * * \\
(0.271)\end{array}$ & $\begin{array}{c}3.208 * * * \\
(0.284)\end{array}$ \\
\hline Intercept & $\begin{array}{c}-4.905 * * * \\
(0.687)\end{array}$ & $\begin{array}{c}-6.739 * * * \\
(0.486)\end{array}$ & $\begin{array}{c}-6.601 * * * \\
(0.488)\end{array}$ \\
\hline Country and Year controls & Yes & Yes & Yes \\
\hline$R^{2}$ & 0.46 & 0.77 & 0.78 \\
\hline Adjusted $R^{2}$ & 0.32 & 0.71 & 0.71 \\
\hline $\mathbf{N}$ & 125 & 125 & 125 \\
\hline
\end{tabular}

Table 2. Effect of workload and hierarchical position on average referral propensity. The data is limited to the three waves of CEPEJ reporting (2010, 2012, 2014). For court tier the reference category is first instance.

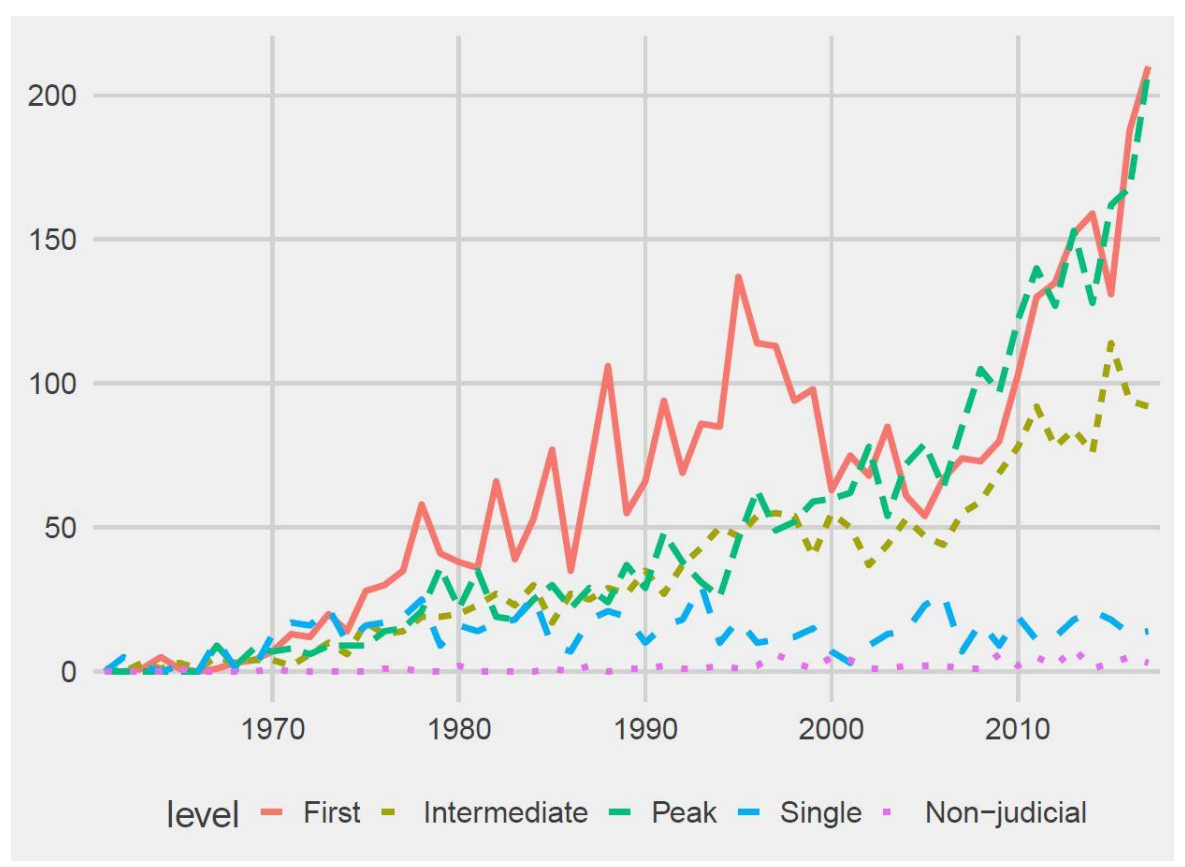

Figure 2. Referral activity by court level, 1961-2017 


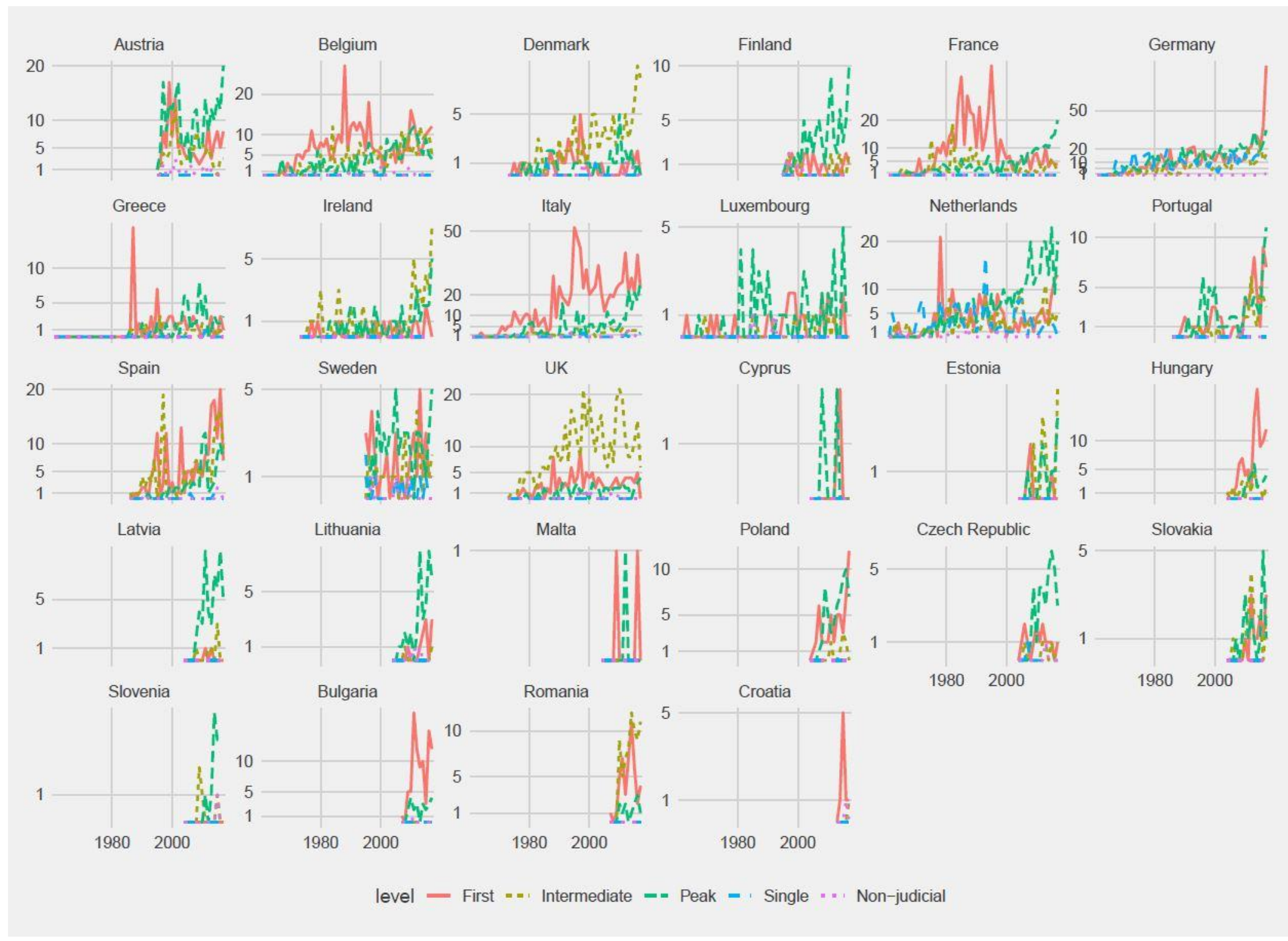

Figure 3. Referral activity by judicial tier and member state, 1961-2017 


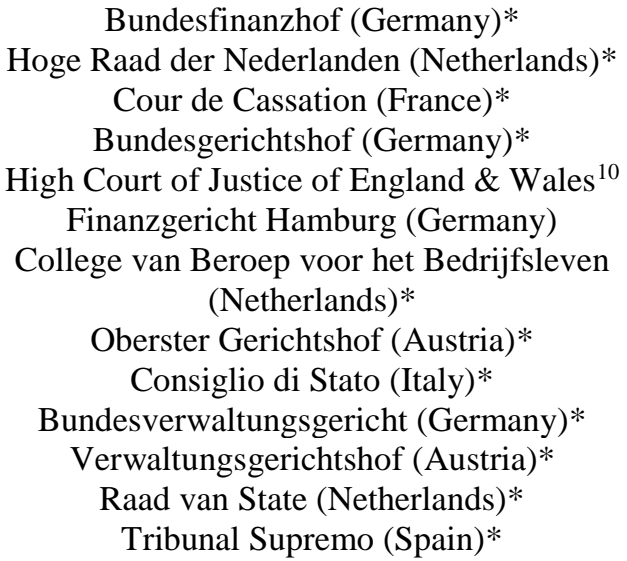

299

$14.2 \%$

$29.1 \%$

$31.5 \%$

$10 \%$

$30.3 \%$

$7.6 \%$

$14.8 \%$

$28 \%$

$13.7 \%$

$5.3 \%$

$23.2 \%$

$11 \%$

$51.6 \%$

Table 1. Most referring courts, 1961-2014. ' ${ }^{\star *}$ ' denotes peak courts.

Taking a closer look at the most referring courts, peak courts also clearly come out on top. Table 1 lists the thirteen most referring courts, as ranked by absolute referral numbers. ${ }^{11}$ Table 1 additionally reports the court's share in the country's overall referral activity. The Court of Justice's most frequent interlocutor, it appears, is the German supreme court for fiscal matters, the Bundesfinanzhof. It is followed by the Dutch Supreme Court (Hoge Raad der Nederlanden) and French supreme court, the Cour de Cassation. As for the Netherlands, the three Dutch supreme courts-Hoge Raad der Nederlanden, College van Beroep and Raad van State-account for nearly 55 per cent of Dutch references. Also appearing in this league table is the Italian Consiglio di Stato, along with the Austrian Oberster Gerichtshof and Verwaltungsgerichtshof - although Austria only joined the EU in 1995. One in every three references coming from Austria is submitted by its two top courts. Save for the High Court of Justice of England and Wales and the Finanzgericht of Hamburg, all the topmost referring courts are peak courts. Moreover, the High Court of Justice's high referral numbers can be explained by the requirement to obtain a leave of appeal to bring cases before the UK Supreme Court. The UK Supreme Court reviews very few cases (see Figure 1), with the effect that most EU law questions wind up on the docket of intermediate tier courts. The high figures for the Finanzgericht of Hamburg, meanwhile, are a manifestation of the exceptionally high degree of participation of German tax courts in the preliminary ruling system.

Overall, these patterns are consistent with our theoretical framework but harder to square with the other theories advanced in the literature. The legal model, alone, cannot explain the observed temporal shifts, because the formal legal rule, Article 267 TFEU has remained unchanged. The relationship between the ECJ and national courts has undergone a process of institutional change but this process has been structured by emerging informal norms interacting with formal rules. In that regard, the judicial

\footnotetext{
${ }^{10}$ Includes references from High Court of Justice's Queen's Bench Division, Chancery Division and Family Division.

${ }^{11}$ Analysis is restricted to 1961-2014 due to missing information on a large number of referring courts awaiting the requested preliminary ruling.
} 
dynamics that have developed around Article 267 represent a compelling illustration of how fixed formal rules interact with informal processes to produce institutional change (Brousseau and Raynaud 2011; Greif and Laitin 2004; Kingston and Caballero 2009; North 1990). Next, the rise of peak courts is hard to reconcile with Karen Alter's court competition hypothesis and the contention that lower courts are the engine of legal integration (Alter 1998, 2001). Lower court judges, especially at a more advanced stage of integration, do not have stronger structural incentives to use Article 267 than their higher court counterparts. On the contrary, higher resource/workload ratios, a focus on law-finding and the lock-in effect of institutionalisation imply that, in a more integrated EU legal order, top courts will have a higher propensity to request preliminary rulings. Reconciling Weiler's empowerment thesis with our data may seem easier but only because Weiler was somewhat equivocal about the behaviour of supreme courts (Weiler 1991, 1994). To the extent that the growing concentration of referral activity in supreme courts is a phenomenon we observe in most member states and by no means one circumscribed to France or allegedly "centralised" judiciaries, our results also contradict the claims of Kelemen and Pavone (2018).

Lending further support to the argument that institutionalisation has put greater pressure on peak courts to submit references is the behaviour of constitutional courts. The empowerment hypothesis implied that, of all domestic judicial bodies, constitutional courts would have the strongest incentives to resist legal integration. An explanation that dovetails well with the data, at least up to the turn of the millennium, as Figure 1A in the Appendix illustrates. Not only did many constitutional judges go out of their way to place limitation on the domestic application of supremacy and direct effect (Dyevre 2013; Kumm 2005), but their referral activity was conspicuous for its absence. Save for the Belgian and Greek constitutional courts, which submitted a couple of references in the 1980s and 1990s, constitutional judges shunned Article 267. Since 2003, however, these judicial bodies appear to have changed track. While constitutional tribunals continue to account for only a modest share of preliminary references, the EU has witnessed a host of constitutional premieres in the last 15 years, with the Austrian Verfassungsgerichtshof, the French Conseil Constitutionnel, the German Bundesverfassungsgericht, the Italian Corte costituzionale, the Spanish Tribunal Constitucional, the Lithuanian Konstitucinis Teismas, the Maltese Constitutional Court and the Slovenian Ustavno sodišče all submitting their maiden reference. Predicting that constitutional courts will become enthusiastic users of the preliminary ruling mechanism would be premature. Yet this evolution supports our institutionalisation hypothesis.

\section{Conclusion}

This paper tries to contribute to the scholarly debate on the dynamics of the preliminary ruling procedure at both empirical and theoretical level. At theoretical level, we argue that national courts are influenced by the degree of institutional consolidation of EU law as well as by organisational factors, including variations in resource allocation and workload across levels of the judicial hierarchy. Through their effect on the courts' environment and audiences, these factors explain temporal shifts in referral 
behaviour. Because top courts enjoy higher resource/workload ratios and concentrate on law-finding, we argued that they should display a higher propensity to request preliminary rulings as the locked-in effect of integration increases the pressure to observe EU law. Empirically then, we show that first instance courts did pioneer the use of the preliminary ruling procedure. Yet a steady rise in references from peak courts led these to overtake lower courts in the mid-2000s. Peak courts now dominate Article 267 proceedings; and this in most member states. Our empirical findings debunk the notion that peak courts are referral-shy as outdated. Instead, the patterns emerging from the data are consistent with our preferred theoretical argument. Both institutionalisation and management constraints have the power to explain shifting patterns of referral activity across courts and time.

\section{Bibliography}

Alter, Karen J. 1998. "Explaining National Courts Acceptance of European Court Jurisprudence: A Critical Evaluation of Theories of Legal Integration." In The European Court and National Courts Doctrine and Jurisprudence, eds. Anne-Marie Slaughter, Alec Stone Sweet, and J.H.H. Weiler. , 232.

. 2001. Establishing the Supremacy of European Law: The Making of an International Rule of Law in Europe. Oxford University Press Oxford.

- 2012. "The Global Spread of European Style International Courts." West European Politics 35(1): 135-54.

Ash, Elliott, and W. Bentley MacLeod. 2015. "Intrinsic Motivation in Public Service: Theory and Evidence from State Supreme Courts.” The Journal of Law and Economics 58(4): 863-913.

Broberg, Morten, and Niels Fenger. 2013. "Variations in Member States' Preliminary References to the Court of Justice-Are Structural Factors (Part of) the Explanation?" European Law Journal 19(4): 488501.

2014. Preliminary References to the European Court of Justice. Oxford University Press.

Brousseau, Eric, and Emmanuel Raynaud. 2011. "“Climbing the Hierarchical Ladders of Rules': A LifeCycle Theory of Institutional Evolution.” Journal of Economic Behavior \& Organization 79(1-2): 6579 .

Burley, Anne-Marie, and Walter Mattli. 1993. "Europe Before the Court: A Political Theory of Legal Integration." International organization 47(01): 41-76.

Carrubba, Clifford J., and Lacey Murrah. 2005. "Legal Integration and Use of the Preliminary Ruling Process in the European Union.” International Organization 59(02): 399-418.

Claes, Monica. 2006. The National Courts' Mandate in the European Constitution. Oxford [u.a.]: Hart.

Conant, Lisa J. 2001. "Europeanization and the Courts: Variable Patterns of Adaptation among National Judiciaries." In Transforming Europe: Europeanization and Domestic Change, eds. Maria Green Cowles, James A. Caporaso, and Thomas Risse-Kappen. Cornell University Press.

De la Mare, Thomas. 1999. “Article 177 in Social and Political Context." In The Evolution of EU Law, eds. Paul Craig and Grainne de Búrca. , 215-60.

Dyevre, Arthur. 2013. "European Integration and National Courts: Defending Sovereignty under Institutional Constraints?" European Constitutional Law Review (EuConst) 9(01): 139-68. 
Epstein, Lee, William M. Landes, and Richard A. Posner. 2013. The Behavior of Federal Judges: A Theoretical and Empirical Study of Rational Choice. Harvard University Press.

Golub, Jonathan. 1996. "The Politics of Judicial Discretion: Rethinking the Interaction between National Courts and the Eurpean Court of Justice.” West European Politics 19(2): 360-85.

Greif, Avner, and David D. Laitin. 2004. "A Theory of Endogenous Institutional Change.” American Political Science Review 98(4): 633-52.

Kelemen, Daniel R, and Tommaso Pavone. 2016. "Mapping European Law." Journal of European Public Policy 23(8): 1118-1138.

- 2018. "The Political Geography of Legal Integration: Visualizing Institutional Change in the European Union.” World Politics 70(3): 358-97.

Kingston, Christopher, and Gonzalo Caballero. 2009. "Comparing Theories of Institutional Change." Journal of Institutional Economics 5(2): 151-180.

Kornhauser, Lewis A. 1994. "Adjudication by a Resource-Constrained Team: Hierarchy and Precedent in a Judicial System.” S. Cal. L. Rev. 68: 1605.

1999. “Appeal and Supreme Courts.” Encyclopedia of Law.

Kumm, Mattias. 2005. "The Jurisprudence of Constitutional Conflict: Constitutional Supremacy in Europe before and after the Constitutional Treaty.” European Law Journal 11(3): 262-307.

de la Mare, T. 1999. "Article 177 in Social and Political Context." In The Evolution of EU Law, eds. Paul Craig and Gráinne de Búrca. Oxford: Oxford university press.

Mayoral, Juan A., Urszula Jaremba, and Tobias Nowak. 2014. "Creating EU Law Judges: The Role of Generational Differences, Legal Education and Judicial Career Paths in National Judges' Assessment Regarding EU Law Knowledge.” Journal of European Public Policy.

North, Douglass C. 1990. Institutions, Institutional Change and Economic Performance. Cambridge university press.

Pierson, Paul. 1996. "The Path to European Integration: A Historical Institutionalist Analysis." Comparative Political Studies 29 (2): 123-163.

Rawlings, Richard. 1993. "The Eurolaw Game: Some Deductions from a Saga." Journal of Law and Society 20: 309-40.

Romeu, Francisco Ramos. 2006. "Law and Politics in the Application of EC Law: Spanish Courts and the ECJ 1986-2000." Common Market L. Rev. 43: 395.

Stephenson, Matthew C. 2009. "Legal Realism for Economists." The Journal of Economic Perspectives 23(2): 191-211.

Stone Sweet, Alec, and Thomas L Brunell. 1998. "The European Court and the National Courts: A Statistical Analysis of Preliminary References, 1961-95." Journal of European Public Policy 5(1): 6697.

Sweet, Alec Stone, and Thomas L. Brunell. 1998. "The European Court and the National Courts: A Statistical Analysis of Preliminary References, 1961-95." Journal of European Public Policy 5(1): 6697.

Weiler, J. H. H. 1991. “The Transformation of Europe.” Yale Law Journal: 2403-2483. 1994. “A Quiet Revolution.” Comparative Political Studies 26(4): 510-534. 
Wind, Marlene. 2010. "The Nordics, the EU and the Reluctance Towards Supranational Judicial Review.” JCMS: Journal of Common Market Studies 48(4): 1039-63.

Wind, Marlene, Dorte Sindbjerg Martinsen, and Gabriel Pons Rotger. 2009. "The Uneven Legal Push for Europe Questioning Variation When National Courts Go to Europe." European Union Politics 10(1): 63-88.

\section{APPENDIX}

\section{A. References from Constitutional Courts}

Figure 1A plots referrals from constitutional tribunals.

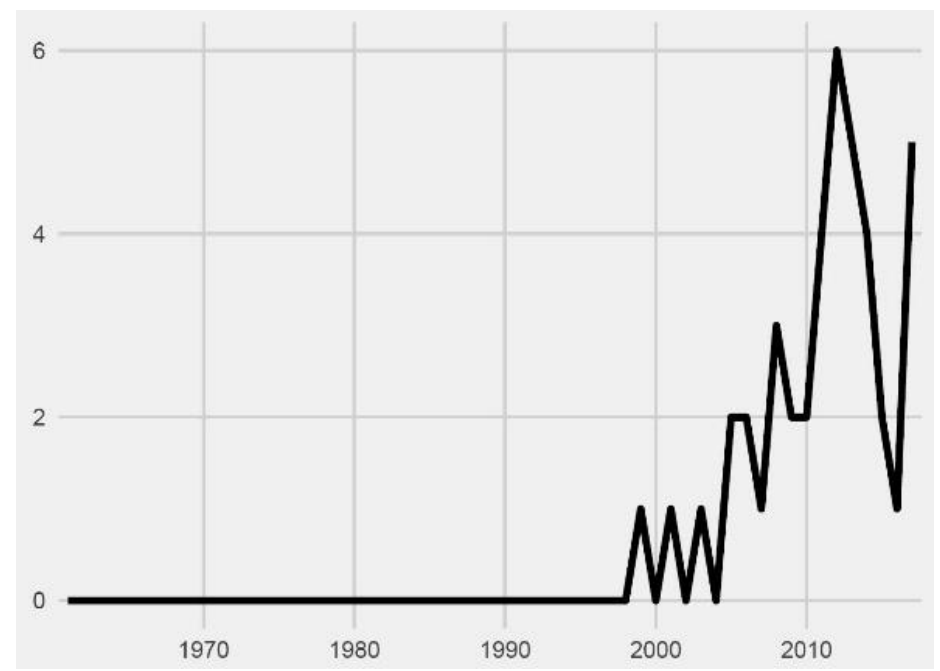

Figure 1A. Referral activity, constitutional courts, 1961-2017

\section{B. Referral Rates by Subject Matter Jurisdiction}

Because subject matter authority varies considerably in how it is delineated across countries, the data was coded using a coding protocol with 17 categories designed to capture as many nuances as possible. The subject matter definitions and corresponding codes are displayed in Table 1B. These codes were then merged to obtain the more general categories used in the analysis below. 


\begin{tabular}{|l|l|}
\hline Subject matter & Code \\
\hline Civil/criminal & 1 \\
\hline Administrative & 2 \\
\hline Courts dealing with constitutional matters & 3 \\
\hline Finance/tax & 4 \\
\hline Social & 6 \\
\hline Labour & 7 \\
\hline Social/Labour & 8 \\
\hline Commerce & 9 \\
\hline Arbitration tribunal/court & 10 \\
\hline Intellectual property (patents, trademarks, copyrights, personal data) & 11 \\
\hline Specialised agencies and non-judicial bodies. & 12 \\
\hline Civil/criminal/administrative & 13 \\
\hline Civil/criminal/fiscal & 14 \\
\hline Family law & 15 \\
\hline Civil/criminal/constitutional & 16 \\
\hline Administrative/labour/social (only for Hungary) & 17 \\
\hline
\end{tabular}

\section{Table 1B. Coding scheme, subject matter jurisdiction.}

We first consider a five-category classification: (1) civil, (2) administrative, (3) constitutional, (4) nonjudicial and (5) other. For this purpose we merge code 1, 6, 7, 8, 9, 13, 14 and 15 to obtain the category "civil"; code 2, 4, and 17 to obtain the category "administrative" and code 3 and 16 to obtain the category "constitutional". Meanwhile, "other" corresponds to code 10 and 11 and "non-judicial" to code 12. Applying this classification, Article 267 use appears to differ according to the courts' subject matter jurisdiction. On the face of things, it looks as if Figure 1B is suggesting that civil courts make more frequent referrals than administrative ones. But this, presumably, is simply an artefact of civil courts processing a larger caseload. ${ }^{12}$ More significant probably is the differential between civil and administrative, on the one hand and the three remaining categories (constitutional, other and nonjudicial), on the other.

\footnotetext{
${ }^{12}$ French civil courts, for example, handle four times more cases than their administrative counterparts.
} 


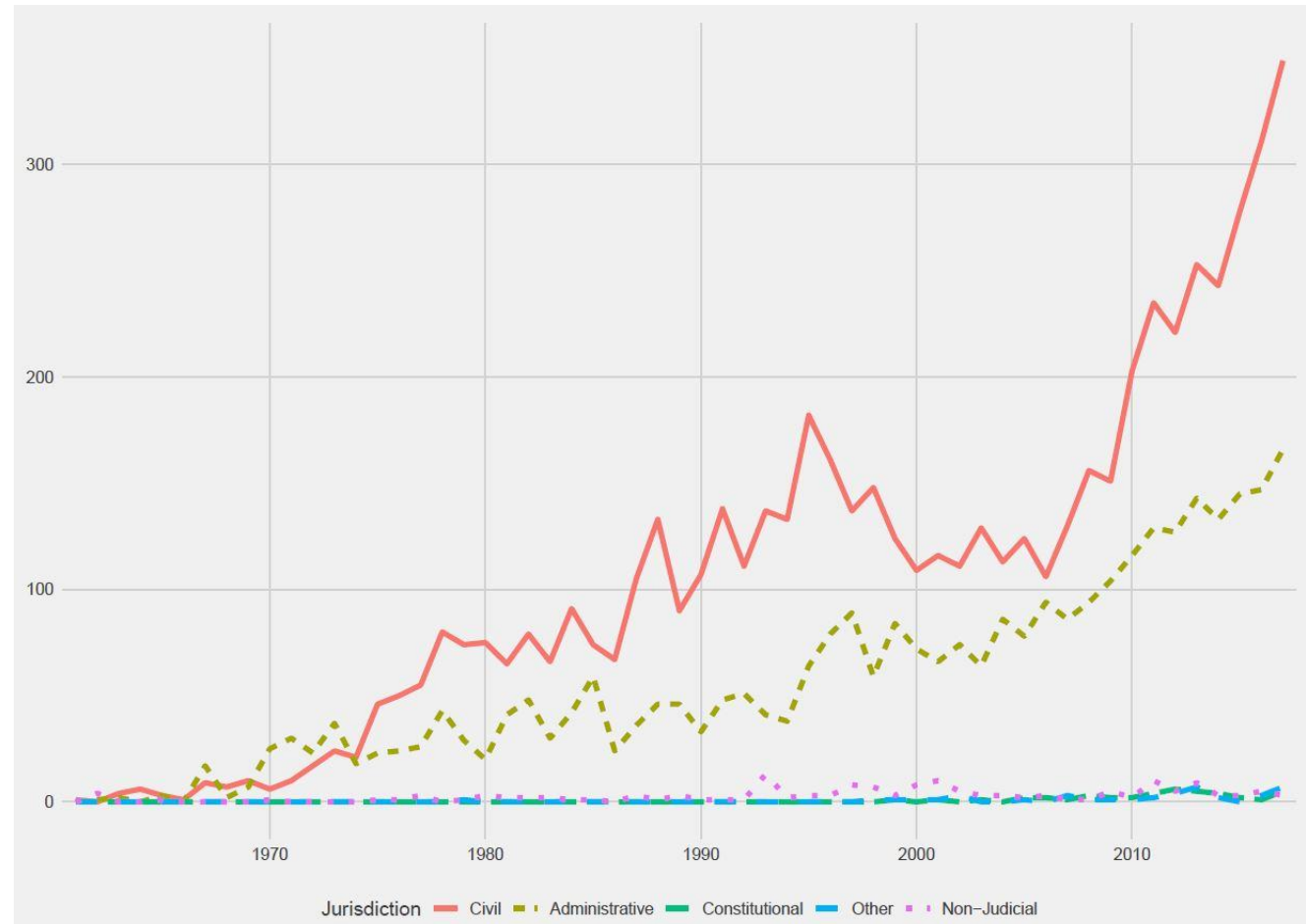

Figure 1B. Referral rates by subject matter jurisdiction, 1961-2017

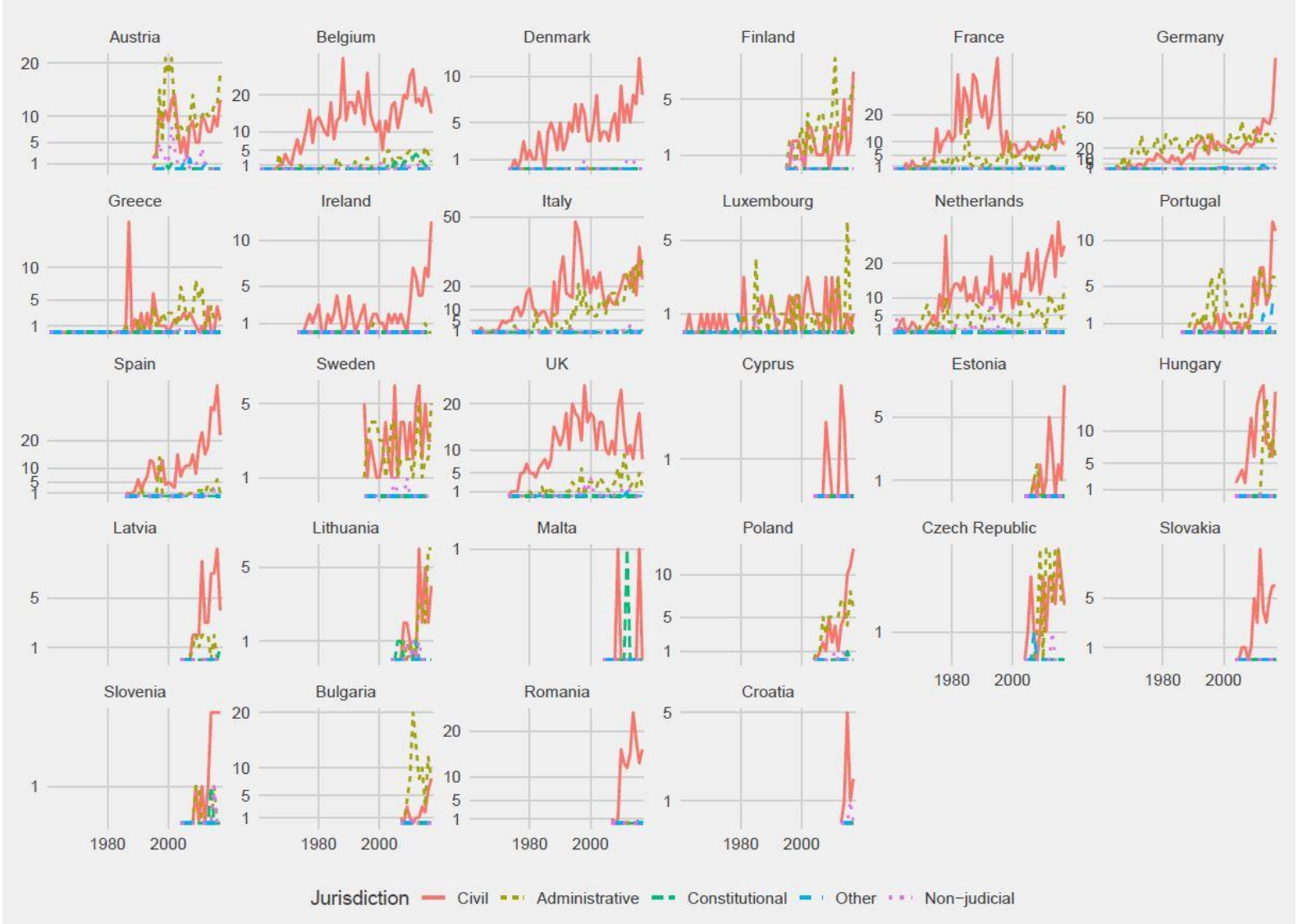

Figure 2B. Referral rates by subject matter jurisdiction and member state, 1961-2017 
How does the picture look like across member states? From the data visualisation in Figure 2B we see that civil courts come out on top of the referral league tables in nearly every member state. Noteworthy are the dynamics observed in founding member states like France and Italy, where administrative courts initially lagged behind in referral activity but have been catching up on civil ones. The evolution characterising the referral behaviour of French administrative judges is, plausibly, a consequence of the jurisprudential U-turn taken by the Conseil d'État in the late 1980s, when it put an end to its protracted tug-of-war with the Court of Justice and finally embraced European integration (Alter 2001, 145). In other member states with high referral rates, such as Austria and the Netherlands, civil and administrative courts have been virtually tied since these countries became part of the EU.

At first sight, German administrative courts, with referral rates consistently higher than civil courts, look exceptionally active. Yet this is largely an artefact of our operationalisation of the category "administrative" courts. Unlike judiciaries in Belgium, the Netherlands, France, Italy, or Swedenwhich are essentially structured around two judicial hierarchies, administrative and civil— the German court system comprises of five hierarchies — civil, administrative, labour, social and tax-each overseen by its own supreme court. Of these five hierarchies, the one formed by tax courts accounts for a very substantive chunk of the references submitted by German courts. So including tax courts in the administrative category meant it would automatically inflate referral rates for this category.

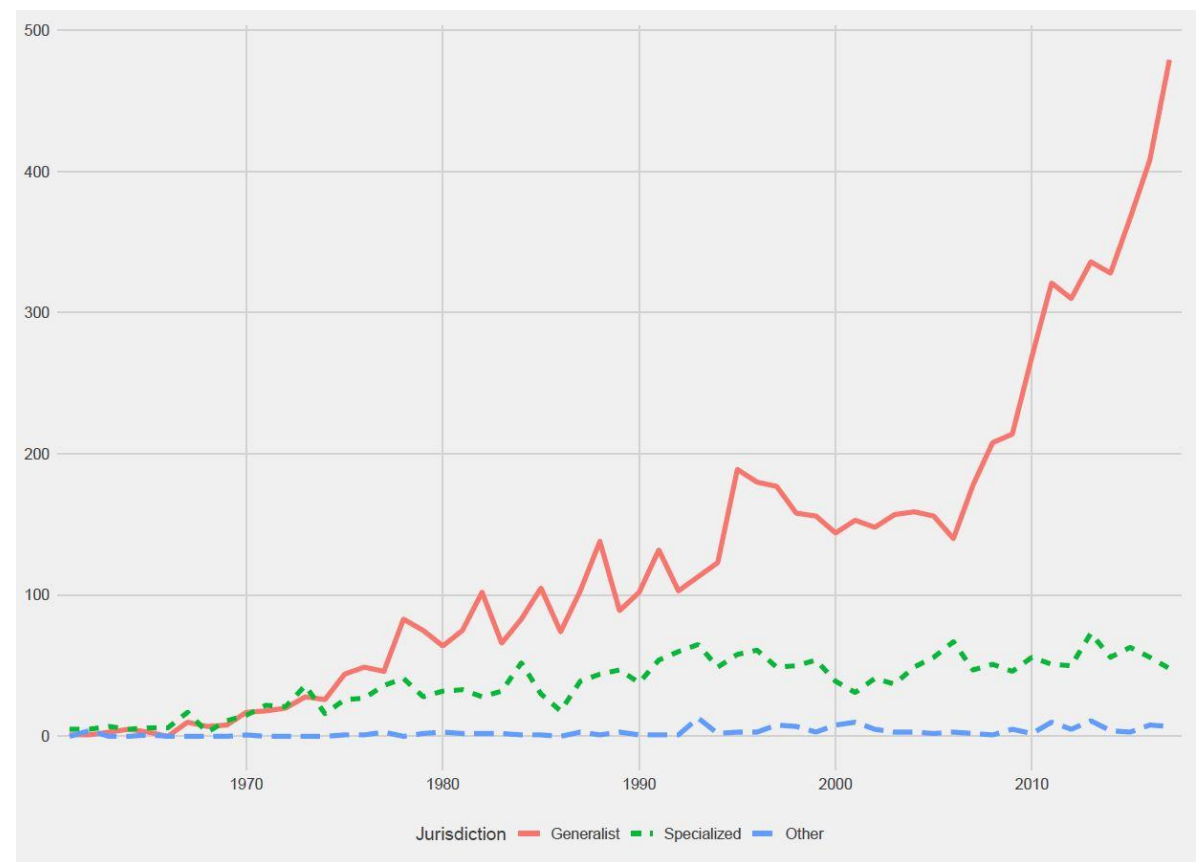

Figure 3B. References, by generalist vs specialised courts, 1961-2017

An alternative classification we also consider distinguishes "generalist" and "specialised" courts. We take the category "generalist" to encompass code 1, 2, 3, 13, 14, 15, 16 and 17 and "specialist" all the other codes except 10 and 12-the latter forming the category "other". This classification clearly puts the generalist judges ahead (Figure 3B). What is more, the gap between the two groups has grown 
considerably over time. Only in Germany do specialised courts come out on top, at least until around 2010 (see Figure 4B). But that is because tax courts, this time, are included in this group.

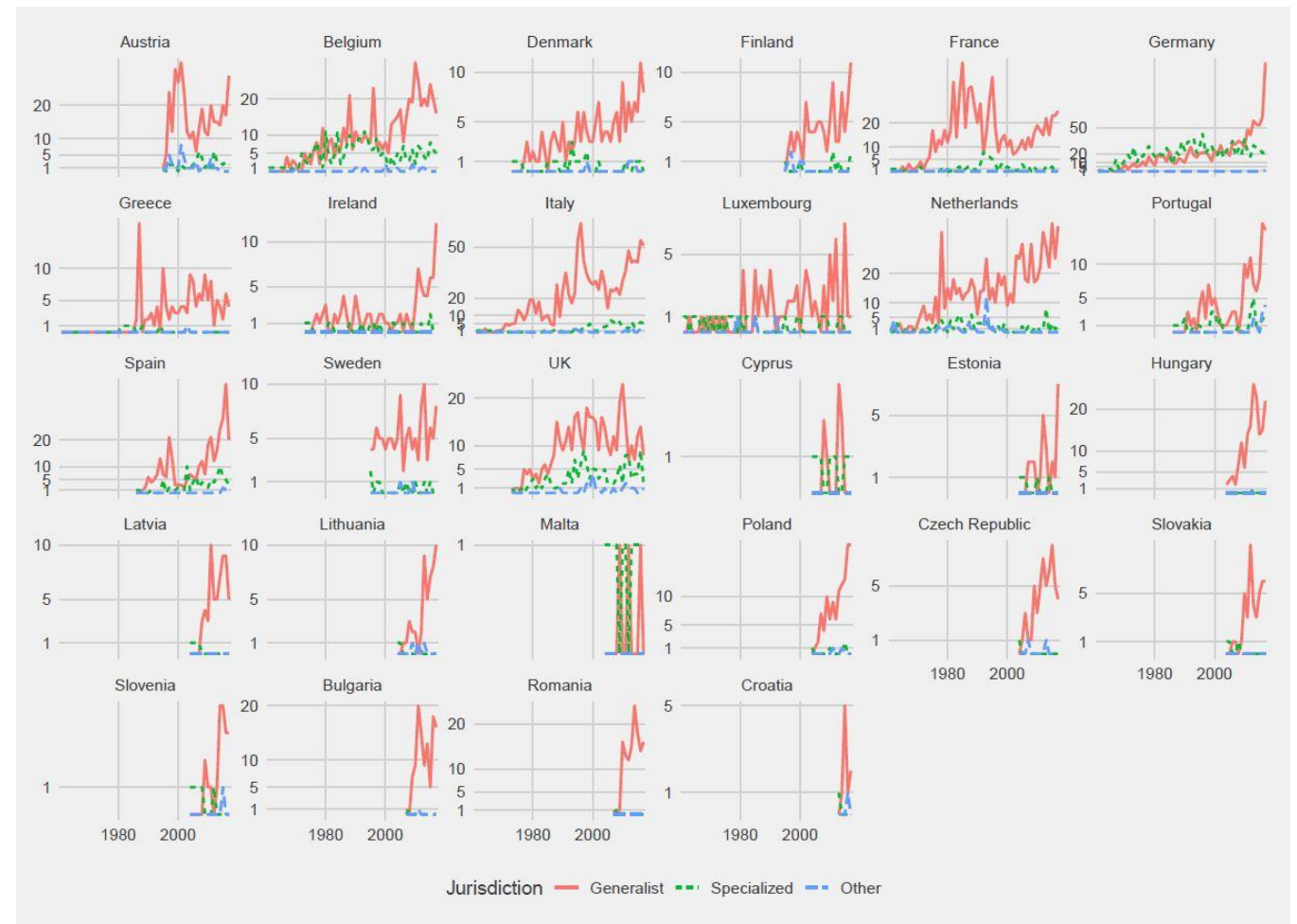

Figure 4B. Specialised vs generalist courts by member state, 1961-2017

While there are, admittedly, many ways to look at the data and to classify judicial bodies, these patterns do not offer conclusive evidence for the claim that jurisdictional specialisation, or focus on commercial litigation correlates with higher referral propensity (Broberg and Fenger 2014a; De la Mare 1999) or that administrative courts are shunning Article 267 (Stone Sweet and Brunell 1998). Civil courts, it is true, tend to submit more than administrative ones. But the difference is not such that we can really say that it generally supports the view that administrative courts are reluctant to pass on questions to the Luxembourg Court or that administrative litigation is less conducive to this form of inter-judicial dialogue. These claims may well have been overdetermined by the situation that prevailed in some big member states prior to the 1990s (e.g. low referral rates for French and Italian administrative courts). In any case, they do not appear to generalise to a more comprehensive picture of referral dynamics. 
